\title{
ARTYKUŁY
}

Klio. Czasopismo poświęcone dziejom Polski i powszechnym

PL ISSN 1643-8191, t. 28 (1)/2014, s. 3-29

(c) $(1) \Theta$

DOI: http://dx.doi.org/10.12775/KLIO.2014.001

PRZEMYSŁAW SZPACZYŃSKI

(Zielona Góra)

\section{Anna I Jagiellonka kontra Jan Zamoyski. Kilka uwag $w$ sprawie dążeń królowej do zapewnienia ciągłości dynastii Jagiellonów}

R ola Anny I Jagiellonki (1523-1596, panowała od 1575 roku) W w doprowadzeniu do elekcji siostrzeńca Zygmunta (1566-
-1632 , król Polski od 1587, król Szwecji 1592-1599, tytuł do 1632) na tron Rzeczypospolitej Obojga Narodów po śmierci Stefana I Batorego (1533-1586; król zmarł 12 XII, elekcja odbyła się w 1575 roku) jest zagadnieniem, które nie zostało dotychczas należycie wyeksponowane $\mathrm{w}$ historiografii. W opracowaniach polskich $^{1}$

1 J. Caro, Das Interregnum Polens im Jahre 1587 und die Parteikämpfe der Häuser Zborowski und Zamoyski, Gotha 1861; K. E. Sieniawski, Das Interregnum und die Königswahl in Polen vom Jahre 1587, Breslau 1869; C. Nanke, $Z$ dziejów polityki Kurii Rzymskiej wobec Polski (1587-1589), Odb. Lwów 1921; K. Lepszy, Walka stronnictw w pierwszych latach panowania Zygmunta III, Kraków 1929; Ł. Żłobińska, Propaganda morska w publicystyce proszwedzkiej w okresie trzeciego bezkrólewia (1587), „Rocznik Gdański” 1980, t. 40, z. 1, s. 112 -128; H. Lulewicz, Gniewów o unię ciąg dalszy. Stosunki polsko-litewskie w latach 1569-1588, Warszawa 2002; J. Dzięgielewski, Sejmy elekcyjne, elektorzy, elekcje 1573-1674, Pułtusk 2003; T. Kempa, Plany separatystycznej elekcji w Wielkim Księstwie Litewskim w okresie trzech pierw- 
i zagranicznych ${ }^{2}$ badaczy więcej uwagi poświęcił tej kwestii jedynie Henry Biaudet, wypaczając jednak całkowicie intencje królowej jako - jego zdaniem - „bezwzględnie pożądającej władzy”" Wielu polskich historyków powielało do pewnego stopnia ten sąd poprzez sprowadzenie intencji Anny I do chęci „odegrania” się za doznane krzywdy i wzmocnienia swej roli u boku siostrzeńca. Ba, podkreślano rzekome rozczarowanie Anny niechętną postawą Zygmunta III wobec jej aspiracjił . Ponadto więcej „zasług”

szych bezkrólewi po wygaśnięciu dynastii Jagiellonów (1572-1587), „Zapiski Historyczne” 2004, z. 1, s. 23-60; J. Dzięgielewski, Jana Zamoyskiego gra o tron Rzeczypospolitej w latach 1587-1589, [w:] Przesztość i teraźniejszość. Prace ofiarowane Profesorowi Adamowi Koseskiemu w siedemdziesiątą rocznicę urodzin, red. M. Dygo i in., Pułtusk 2009; A. Pieńkowska Zjazdy i sejmy z okresu bezkrólewia po śmierci Stefana Batorego, Pułtusk 2010.

${ }^{2}$ V. Tomek, Snahy domu rakouskeho o nabyti koruny polske $v$ šestnáctem stoleti, „Časopis Českeho Musea” 1853, t. 27, s. 744-788; E. E. Mayer, Des Olmützer Bischofes Stanislaus Pawtowski Gesandtschaftsreisen nach Polen aus Anlass der Königswabl nach dem Ableben Stefan I. (1587-1598). Nach den handschriftlichen Quellen des k. k. geh. Haus-, Hof-und Staats-Archivs zu Wien und des Olmützer fürsterzbischöflichen Archivs zu Kremsier, Odb. Wien 1861; K. Haselbach, Österreich und die polnische Königswahl v. 1587, [w:] Jaresbericht über d. k. k. Josephstädter Ober-Gymnasium, Wien 1869; P. Karge, Das örterreichische Unternehmen auf Polen und die Schlacht bei Pitschen 1588, "Zeitschrift für osteuropäische Geschichte und Alterthum Schlesiens" 1888, Bd. 22, s. 116-150; R. Hassencamp, Papst Sixtus des Fünften und polnische Politik, insbesondere seine Stellungnahme zur Königswabl v. 1587, „Zeitschrift der historischen Gesellschaft für der Provinz Posen” 1889, Bd. 4, s. 49-68; S. Ehses, Das polnische Interregnum 1587, „Römische Quartalschrift für christliche Altertumskunde und für Kirchengeschichte” 1895, Bd. 9, s. 377; J. Schweizer, Antonio Possevino S. J. und die polnische Sukzessionsfrage im Jahre 1587, „Römische Quartalschrift für christliche Altertumskunde und für Kirchengeschichte” 1909, Bd. 23, s. 173; H. Biaudet, Sixte Qiunti et la candidature de Sigismond de Suède au trône de Pologne en 1587, d'après de documents inèditis deo Archives Secrètes du SaintSiegè, Helsinki 1910; idem, Les origines de la candidature de Sigismond Vasa au trône de Pologne en 1587, Helsingfors 1911; H. Almquist, Den politiska krisen och konungavalet i Polen år 1587, Göteborg 1916; J. Macůrek, Dozvuky polského bezkráloví z roku 1587. Príspèvek $k$ osvètneni snah rodu habsburského o ziskáni koruny polské v letech 1588-94, Praha 1929; Б. Н. Флоря, „Бескоролевье” 1587 г. в Речи Посполитой и проблема антитуреикой коалиции, [w:] Юго-Восточная Европа в средне века, Книшинев 1972; W. Leitsch, Sigismund III. von Polen und Jan Zamoyski. Die Rolle Estland in der Rivalität zwischen König und Hetman, Wien 2006.

${ }^{3}$ H. Biaudet, Les origines..., s. 9-11.

${ }^{4}$ M. Bogucka, Anna Jagiellonka, Wrocław 1994, s. 146-156. 
w doprowadzeniu do elekcji potomka Jagiellonów w historiografii polskiej przypisywano kanclerzowi i hetmanowi Janowi Zamoyskiemu (1542-1605), który obronił Kraków, oblegany przez głównego kontrkandydata Zygmunta, arcyksięcia Maksymiliana Habsburga (1558-1618), a następnie pokonał go pod Byczyną i wziął do niewoli. Bezkrytyczni wielbiciele kanclerza - a miał i ma takich wielu nawet wśród wybitnych badaczy - eksponowali jego rolę przede wszystkim po to, aby móc wytknąć królowi niewdzięczność wobec Zamoyskiego ${ }^{5}$. Prawdziwe intencje kanclerza odkryte dzięki pracom Jana Dzięgielewskiego czy Waltera Leitscha oraz piszącego te słowa, pozwalają dziś stwierdzić, że król Zygmunt III nie miał za co być „wdzięczny” Zamoyskiemu, który był w istocie wielkim przeciwnikiem jego wyboru na tron Rzeczypospolitej ${ }^{6}$. Problem z eksponowaniem roli Anny I Jagiellonki polegał głównie na tym, że królowa, walcząc o tron dla siostrzeńca, dążyła do zapewnienia ciągłości dynastii Jagiellonów, do której historycy nie zaliczyli Zygmunta III i jego synów, wyznaczając bezceremonialnie jej kres na 1572 rok, i co ciekawe, nie bacząc przy tym na fakt, że Anna I również była władczynią z dynastii Jagiellonów.

Po śmierci króla Stefana I Batorego, mimo ogłoszonego bezkrólewia, na tronie formalnie nadal pozostawała Anna I Jagiellonka, której po wyborze (15 XII 1575) Batory został jedynie „przydany na męża” i wraz z nią ukoronowany na Wawelu (1 V 1576) ${ }^{7}$. W dodatku „ostatnia z rodu” nie

5 J. Dzięgielewski, Jana Zamoyskiego..., s. 81-88.

${ }^{6}$ W. Leitsch, Sigismund III..., passim; J. Dzięgielewski, Czym Jan Zamoyski „zarobit" na chwate, a Jerzy Ossolinski na niestawe, czyli o wyższości kreujacych wizerunek nad wypetniajacymi powinności, [w:] Studia Historyczno-Prawne poświęcone pamięci Profesora Jana Seredyki, red. W. Kaczorowski, Opole 2008, s. 129-138; idem, Dlaczego projekt nowelizacji artykutów henrykowskich z 1587 roku zostat zapoznany?, [w:] $Z$ dziejów kultury prawnej. Studia ofiarowane Profesorowi Juliuszowi Bardachowi w dziewięćdziesięciolecie urodzin, red. A. Rosner i in., Warszawa 2004, s. 553-557; idem, Jana Zamoyskiego..., s. 81-88; P. Szpaczyński, Mocarstwowe dązenia Zygmunta III w latach 1587-1618, Kraków 2013.

${ }^{7}$ Imię Anny stało na pierwszym miejscu nie tylko przez wzgląd na szacunek dla pamięci Jagiellonów, lecz przede wszystkim dlatego, że król Stefan I miał być małżonkiem królowej. Królem formalnie został niejako pośrednio. Zgodnie z wciąż obowiązującymi średniowiecznymi obyczajami, nie znającymi instytucji „księcia małżonka”, mąż panującej królowej stawał się również królem i przejmował władzę nad krajem. Państwo polskie znów, jak niegdyś za Jadwigi I (1373-1384-1399) i Władysława II Jagiełły (1351-1386-1434), miało dwóch prawowitych królów. Zaistniały współrządy. Anna jednak, podobnie 
miała zamiaru rezygnować z powyższego atutu, o czym najlepiej świadczy to, że już dziesięć dni po śmierci Batorego podkanclerzy litewski Lew

jak Jadwiga I, w praktyce nie nadawała kierunku ważnym sprawom państwa. Poza tym nie była, jak Jadwiga I, „przyrodzoną panią Królestwa”, bo Jagiellonowie w przeciwieństwie do Piastów (ostatnim Piastem na polskim tronie po kądzieli była Jadwiga I) byli królami elekcyjnymi, Dyplom elekcyjny Anny Jagiellonki i Stefana Batorego, Warszawa, 15 grudnia 1575 r., [w:] Báthory István erdélyi fejedelem és lengyel király levelezése, t. 1: (1556-1577), wyd. E. Veress, Kolozsvár 1944, s. 373-377; por.: współczesny druk ulotny bez daty i miejsca wydania Jagietta i Echa rozmowy o potomku swym, obranym na Królestwo Polskie, o Królewnie J. M. Annie, z taski Bożej Królowej polskiej, wespotek o matżonku J. K. M. Najjániejszym Stefanie pierwszym, królu polskim, niniejszym, [w:] Okolicznościowa poezja polityczna w Polsce. Pierwsi królowie elekcyjni, wyd. J. Nowak-Dłużewski, Warszawa 1969, s. 92; I. Horn, A könnyezo krokodyl. Jagello Anna es Báthory István, házassága, Budapeszt 2007; Anna nie była zachwycona faktem, że za męża jej, królewskiej córce, proponuje się księcia-wojewodę i tureckiego lennika. Jak sama jednak przyznała, przezwyciężyła opory, gdyż wolała być królową niż małżonką syna królewskiego, Relacje elekcyi Stefana Batorego, [w:] Wiadomości do dziejów polskich z Archiwum Prowincji Szlaskiej, wyd. A. Mosbach, Wrocław 1860, s. 104. W naukowym dyskursie historycznym zamiast określenia „Anna Jagiellonka” winno funkcjonować Anna I Jagiellonka”, wówczas nie byłoby żadnej wątpliwości, w jakim sensie królową była „ostatnia z rodu” Jagiellonów po mieczu. Tym bardziej, że ów tytuł dumna Jagiellonka okupiła upokarzającym zrzeczeniem się na oczach dostojnych świadków koronacji w katedrze wawelskiej olbrzymich skarbów - dóbr i kosztowności, które uczyniłyby ją potężną w Rzeczypospolitej - co było bez wątpienia jej nadzieją i zamiarem. Tymczasem szlachta przy okazji wyboru na króla sprytnie pozbawiła infantkę nie tylko majątków po matce Bonie Sforzy (1492-1557), ale i pretensji do Mediolanu, włoskich księstw Bari i Rossano oraz do słynnych sum neapolitańskich, których odtąd miała dochodzić Rzeczypospolita. Nic dziwnego, że rozżalona i rozgniewana na szlachtę Anna dokument podpisała z płaczem. Fakt lekceważenia i niedoceniania Anny I Jagiellonki w polskiej historiografii oraz fakt powszechnego, błędnego twierdzenia o wygaśnięciu dynastii Jagiellonów w 1572 r. znajduje niestety odzwierciedlenie w historiografii obcej. Przykładem jest m.in. ostatnia książka W. Leitscha, który zdawał się nie wiedzieć, że Anna I Jagiellonka była nie tylko - jak ją określał autor - „córką króla, siostrą króla i wdową po królu”, ale królem. Stąd nie rozumiał, że spór o rangę i ważność osób, który zaistniał podczas wesela Zygmunta III z Anną Rakuską (1573-1598) pomiędzy matką panny młodej, arcyksiężną Marią Krystyną (1551-1608), a Anną Jagiellonką, z punktu widzenia tej ostatniej był uzasadniony. Nieadekwatne określenia autora „stara królowa” i „młoda królowa”, jakie przyjął dla rozróżnienia ciotki i żony króla też zostały oparte na błędnym założeniu, że Anna Jagiellonka była królową w tym samym sensie, co jej imienniczka Rakuszanka, P. Szpaczyński, Spór o Zygmunta III, „Kwartalnik Historyczny" [dalej: KH] 2011, t. 4, s. 737. Biografie królowej, zob.: J. Bartoszewicz, Anna Jagiellonka, Kraków 1882; J. Szujski, Anna Jagiellonka, królowa polska, [w:] idem, Dzieła, Seria 2, t. 5: Opowiadania i roztrzasania historyczne, Kraków 1885, s. 68-69; M. Wrede, Anna Jagiellonka. Szkic biograficzny, Warszawa 1986. 
Sapieha (1557-1633) pisał do wojewody wileńskiego i hetmana polnego litewskiego Krzysztofa Radziwiłła „Pioruna”(1547-1603): „Królowa chce być królem, jako to WMć z listu jej zrozumiesz, a drudzy królewicza szwedzkiego już koronują".

Sześćdziesięcioczteroletnia wówczas monarchini nie zamierzała jednak powtórnie wychodzić za mąż, ani tym bardziej osobiście sprawować władzy. Jeżeli przypominała, że formalnie to ona nadal jest królem, to tylko po to, aby szlachta przy elekcji następcy Batorego miała ograniczony wybór - jak dawniej - do przedstawicieli królewskiego rodu Jagiellonów. Po śmierci brata Zygmunta II Augusta (1520-1572, król od 1548 roku), licząc na małżeństwo z Henrykiem z francuskiej dynastii Walezjuszy (1551-1589, król 1573-1574), a po jego ucieczce - na koronę królewską, nie próbowała działać na rzecz kandydatury, z którą dwukrotnie wystąpił jej szwagier król szwedzki Jan III (1537-1592, panował od 1568 roku), tym bardziej, że ten ostatni $-\mathrm{z}$ racji protestanckiego wyznania i kłopotów z opozycją w Szwecji - z góry skazany był na porażkęe . Jego syn zaś, imiennik i ostatni męski potomek Jagiellonów, Zygmunt, był jeszcze dzieckiem. Anna Jagiellonka jednak tuż przed swym wyborem na tron polski, wysyłając do Szwecji przez zaufanego dworzanina, Wawrzyńca Rylskiego, Janowi III zbroję Zygmunta II Augusta, jasno dawała wyraz swej dynastycznej polityce ${ }^{10}$. Król szwedzki zachował się podobnie, gdy w razie spodziewanego odrzucenia jego kandydatury, nakazał wysłanym na elekcję posłom forsowanie wyboru szwagierki Anny, ponieważ jej osoba miała zapewnić ciagłość dynastii, z której po kądzieli wywodził się jego syn ${ }^{11}$.

${ }^{8}$ L. Sapieha do K. Radziwiłła, Grodno, 22 XII 1586, Archiwum Domu Radziwittów [dalej: ADR], Listy księcia (Mikotaja Krzysztofa) Radziwitta - Jana Zamoyskiego - Lwa Sapiehy, wyd. A. Sokołowski, Scriptores rerum Polonicarum [dalej: SRP], t. 8, Kraków 1885 , s. 186.

${ }^{9}$ K. Ślaski, Tysiaclecie polsko-skandynawskich stosunków kulturalnych, Wrocław-Warszawa-Kraków-Gdańsk 1977, s. 121.

${ }^{10}$ A. Jagiellonka do Jana III, Warszawa, 28 VIII 1574, [w:] H. Biaudet, Le SaintSiège et la Suède durant la secondé moitie du XVIe siècle. Notes et Documents, Études politiques, Paris 1906, t. 1, Dodatki, nr 357, s. 116.

${ }^{11}$ K. Olejnik, Stefan Batory 1533-1586, Warszawa 1988, s. 41. 
Od momentu, gdy na tronie zasiadł „przydany” Jagiellonce za męża książę Siedmiogrodu Stefan Batory, kwestia osadzenia w przyszłości szwedzkiego dynasty na tronie Jagiellonów była stałym elementem w dyskusjach posłów obu stron. Przy czym Batory już trzy miesiące po swojej koronacji nie tylko nie miał nic przeciw temu, aby w przyszłości zastąpił go w Polsce Jagiellon po kądzieli, ale nawet sam wychodził naprzeciw oczekiwaniom żony i szwagra. Już trzy miesiące po koronacji Anny i Stefana, w sierpniu 1576 roku, gdy z warunkami proponowanego przez Jana III sojuszu przeciw Iwanowi IV przybył do Sztokholmu poseł, kasztelan sanocki Jan Herburt (po 1524-1577), po raz pierwszy oficjalnie poruszono kwestię wyboru królewicza Zygmunta, jako Jagiellona po kądzieli, na tron Rzeczypospolitej ${ }^{12}$.

Król Stefan I był zdeterminowany w dążeniu do zjednoczenia swoich ojczystych Węgier, czego zamierzał dokonać po pokonaniu Turcji przy wsparciu Moskwy, której potencjał usiłował wykorzystać ${ }^{13}$. Panowanie w Polsce traktował jako „mizerny czyściec”, który rad był opuścić po zyskaniu sławy tureckiego pogromcy, co też oświadczył wprost na sejmie w 1585 roku, po blisko dziesięciu latach panowania, zapewniając przy tym, że nie zamierza w przyszłości forsować na tron bratanka:

Wszedłem sam in misserrinum purgatorium, by mi nie szło o sławę, puściłbym to królestwo, a miałbych in istam carnificinam synowca dać, dziecię optima indolis? Uchowa mię i jego tego Pan Bóg ${ }^{14}$.

Jan Zamoyski, kanclerz (od 1578) i hetman wielki koronny (od 1581), wykreowany przez Stefana Batorego na „drugiego króla”, ożeniwszy się (w 1583 roku) z królewską bratanicą ${ }^{15}$ liczył, że monarcha, któremu pomoże zrealizować wielkie plany, zabiegając - jak dotąd z wielką dla

${ }^{12}$ R. Żelewski, Herburt Jan, [w:] Polski Stownik Biograficzny [dalej: PSB], t. 9, Wrocław 1960-1961, s. 441.

${ }^{13}$ S. Załęski, Wojenne plany Stefana Batorego w latach 1583-1586, „Przegląd Powszechny" 1884, t. 3, s. 30-50; J. Besala, Stefan Batory, Poznań 2010, s. 425.

${ }^{14}$ Rozmowa z królem Stefanem Andrzeja Opalińskiego marszatka wielkiego koronnego po sejmie warszawskim r. 1585, [w:] Dyaryusze sejmowe z 1585 r., wyd. A. Czuczyński, SRP, t. 18, Kraków 1901, s. 421.

${ }^{15}$ J. Zamoyski ożenił się 12 VI 1583 r. z Gryzeldą Batorówną (zm. 1590), córką Krzysztofa Batorego (1530-1581), Ksiązęta Siedmiogrodu z domów Batorych, Bethlenów, 
siebie korzyścią - o ich poparcie u szlachty, odwdzięczy mu się na końcu przez poparcie jego osoby jako kandydata na tron polski. Problem, jaki stanowiła królewska małżonka, która w razie zrealizowania planów Batorego i jego rezygnacji z korony polskiej dążyłaby do osadzenia na tronie polskim i litewskim siostrzeńca, usiłował rozwiązać zawczasu, namawiając bezceremonialnie Batorego do rozwodu pod pretekstem rzekomej chęci założenia własnej dynastii ${ }^{16}$. Król, zdając sobie wprawdzie sprawę z tego, że został „przydany na męża” żonie-, królowi”, nie myślał póki co dążyć do rozwo$\mathrm{du}^{17}$. Wątpliwe było jednak, aby po urzeczywistnieniu swoich planów - do realizacji których przystąpił w 1586 roku pozostał w Polsce. Na ten moment właśnie, aby nie ubiegł jej Zamoyski, przygotowywała się królowa Anna I. Po sejmie 1585 roku, Jagiellonka wysłała poselstwo do Rzymu celem zyskania przychylności papieża dla przyszłego wyboru siostrzeńca na tron polski, a latem 1586 roku, gdy nic przecież jeszcze nie zapowiadało śmierci jej męża, oświadczyła Habsburgom, u których zabiegała o żonę dla Zygmunta, że osadzi go na tronie Jagiellonów ${ }^{18}$.

O tym, że nie było to bezpodstawne oświadczenie, mające przemawiać na rzecz koligacji nowej szwedzkiej dynastii z Domem cesarskim, miało wówczas świadczyć to, że Zygmunt od dziecka wychowywany był na króla Polski ${ }^{19}$. Po niespodziewanej śmierci Batorego miała to potwier-

Rakoczych i Apafich, [w:] Genealogia - Tablice, oprac. W. Dworzaczek, Warszawa 1959, nr 86.

${ }^{16}$ Exscessi w Rzeczypospolitej znieście, Archiwum Główne Akt Dawnych w Warszawie [dalej: AGAD], Archiwum Publiczne Potockich, nr 6, k. 78.

${ }_{17}$ O tym, że Anna I, czując lęk przed rozwodem, zimą 1579/1580 wymogła na Batorym oświadczenie, że nie podejmie kroków rozwodowych, pisze M. Bogucka, Anna Jagiellonka..., s. 128.

${ }^{18} \mathrm{O}$ misji Żyda o nazwisku Mendel do Grazu zob.: F. Hurter, Geschichte Kaiser Ferdinands II. und seiner Eltern bis zu dessen Krönung in Frankfurt. Personen-, Haus- und Landesgeschichte, Bd. 1-7, Schaffhausen 1850-1854, Bd. 3, s. 7-8; H. Biaudet, Les origines..., s. 15; P. Jasienica, Ostatnia z rodu, Warszawa 1965, s. 315; idem, Rzeczpospolita Obojga Narodów, cz. 1: Srebrny wiek, wyd. 2, Warszawa 1982, s.199; E. Rudzki, Polskie królowe, t. 2: Żony królów elekcyjnych, Warszawa 1987, s. 46-67.

${ }_{19}$ Dyaryusze sejmów koronnych 1548, 1553 i 1570 r., wyd. J. Szujski, SRP, t. 1, Kraków 1872, s. 134; w związku z tym polecił wychowywać go w nadziei objęcia tronów obu królestw nadbałtyckich, J. A. Pärnänen, Sigismond Vasa et la succession au trône de 
dzić elekcja 1587 roku, gdy właśnie nadszedł czas na realizację zamierzenia Anny I Jagiellonki. Było ono zgodne z oczekiwaniami jej szwedzkiego szwagra, króla Jana III, i siostry Katarzyny (1526-1583), która niestety nie doczekała tej chwili ${ }^{20}$. Ponieważ Bałtyk był skuty lodem, drogą okrężną przez Inflanty zdążał do Sztokholmu Lambert Wrader, wysłannik królowej, która, informując swego siostrzeńca o śmierci męża, zapraszała go na tron Jagiellonów jako jedynego ich męskiego potomka - jak to określiła - „ostatnią latorośl krwi zacnych Jagiełłów"21.

Król Szwecji Jan III, odkąd poślubił w Wilnie Katarzynę Jagiellonkę (4 X 1562) i odkąd urodził się ich syn (20 VI 1566), stale planował przejęcie schedy po Jagiellonach. W tym czasie jednak odprawił posła z oświadczeniem, że Zygmuntowi, nawet, gdy zostanie wybrany królem, nie pozwoli na wyjazd do Polski ${ }^{22}$. Wówczas w Vadstenie, gdzie przebywał Jan III wraz z synem, rozpoczynał obrady szwedzki riksdag, na którym rozstrzygano na-

Suéde 1592-1594 d'apres la correspondance diplomatique du nonce apostolique Germanico Malaspina, Genēve 1912, s. 2; O tym, że „z dzieciństwa swego Polszcze za króla i Litwie za Xsiążę był gotowany, po polsku był ćwiczony w nabożeństwie, w obyczajach, języku, polskie statuta czytał z młodości i dobrze rozumie”, Poloneutichia Andrzeja Lubienieckiego, wyd. A. Batowski, Lwów 1843, s. 36. Autor wiersza prezentującego kandydatów do korony zachęcał do wyboru Zygmunta, wskazując na jego jagiellońskie pochodzenie: „Sauromata własny a nie cudzoziemiec [...] z Polki spłodzony niech na państwo siędzie, / Dawnych Jagiełłów plemię, dobrze nam z nim będzie", Wiersze wspótczesne na kandydatów do korony w 1587 r., [w:] Listy Annibala z Kapui, arcybiskupa neapolitańskiego nuncjusza w Polsce, o bezkrólewiu po Stefanie Batorym i pierwszych latach panowania Zygmunta III do wyjścia arcyksięcia Maksymiliana z niewoli..., tłum. z włos. i wyd. A. Przeździecki, Warszawa 1852, s. 250; por.: Historia królów polskich od Kazimierza Jagiellończyka do Wtadystawa IV wierszem opowiedziana, Biblioteka Jagiellońska [dalej: BJ], rkps 922, k. 4-5.

${ }^{20}$ W. Czapliński, Katarzyna Jagiellonka, [w:] PSB, t. 12, Wrocław 1966-1967, s. 218-220; P. O. Törne, Katarzyna Jagiellonka, „Przegląd Współczesny” 1938, R. 17, t. 65 , nr 5, s. 1-19.

${ }^{21}$ Królowej Anny Jagiellonki instrukcyja postom na sejmiki w Wielkim Księstwie Litewskim z zaleceniem nowo obranego króla Zygmunta III w $1587 \mathrm{r}$., [w:] Jagiellonki polskie w XVI wieku. Obrazy rodziny i dworu Zygmunta I i Zygmunta Augusta Królów polskich, t. 4: Listy Anny Jagiellonki, królewny i królowej polskiej 1548-1596, wyd. A. Przeździecki, Kraków 1868, s. 313; B. Paprocki, Dwie broszury polityczne z lat 1587 i 1588, wyd. J. Czubek, Kraków 1900, s. 18.

${ }^{22}$ J. A. Pärnänen, Sigismond Vasa..., s. 3-4. 
rastający od lat konflikt między królem a jego młodszym bratem, księciem Södermanlandii, Karolem (1550-1611, król Szwecji od 1604 roku). Jan III nie chciał zbyt łatwo zgodzić się na elekcję syna w Polsce, aby - widząc jego determinację - szlachta nie stawiała mu w czasie elekcji warunków niemożliwych do spełnienia, które nie tylko osłabiłyby kandydaturę jego syna w Polsce, ale zagroziłyby również przyszłemu panowaniu Zygmunta w Szwecji - i bez tego poważnie zagrożonemu przez stryja.

Królowa, zaskoczona postawą szwagra, nie zamierzała jednak się poddać i starała się zyskać zgodę Jana III, dlatego po powrocie Wradera wysłała go z misją po raz kolejny ${ }^{23}$. Następnie z jej inicjatywy do Szwecji wysłani jeszcze zostali kolejno: Paweł Uchański (1548-1590), Walenty Węglikowski i kasztelan podlaski Marcin Leśniowolski (zm. 1593) ${ }^{24}$. Misja Pawła Uchańskiego, podobnie jak jego poprzednika, zakończyła się fiaskiem. Walenty Węglikowski wyruszył do Szwecji na wieść rozpuszczoną przez Habsburgów, że Jan III i jego syn zostali uwięzieni wskutek zamachu dokonanego przez księcia Karola ${ }^{25}$. Węglikowski nie tylko przywiózł dobrą wiadomość, że „to baśnie były, co powiadano o ich więzieniu czy pojmaniu”26, ale miał również nakłonić Jana III do zmiany stanowiska wobec elekcji Zygmunta ponurą w konsekwencjach dla Szwecji wizją panowania w Rzeczypospolitej cara Fiodora I (1557-1598, panował od 1584 roku) ${ }^{27}$.

${ }^{23}$ H. Biaudet, Les origines..., s. 67-68.

${ }^{24}$ Obok tego ostatniego, spośród senatorów najbardziej wspierali królową w zamyśle osadzenia na tronie siostrzeńca: wojewoda mazowiecki Stanisław Kryski (ok. 1536-1595), płocki Grzegorz Zieliński, kasztelanowie, ciechanowski Stanisław Krasiński (1558-1617), czerski Stanisław Radzimiński (zm. 1591), sochaczewski Stanisław Gostomski (zm. 1598) oraz łęczycki Paweł Szczawiński (1529-1594), pełniący również funkcję ochmistrza dworu królowej, K. Lepszy, Walka stronnictw..., s. 14; por.: H. Kowalska, Leśniowolski Marcin, [w:] PSB, t. 17, Wrocław 1972, s. 181-184; R. Żelewski, Kryski Stanistaw, [w:] PSB, t. 15, Wrocław 1970, s. 486-488; J. Maciszewski, Krasiński Stanistaw, [w: ] ibidem, s. 191-192.

${ }^{25} \mathrm{H}$. Biaudet, Les origines..., s. 36, 41.

${ }^{26}$ Dyaryusze sejmowe, R. 1587: Sejm konwokacyjny i elekcyjny, wyd. A. Sokołowski, SRP, t. 11, Kraków 1887, s. 2.

${ }^{27} \mathrm{O}$ tym, że Jan III rzekomo bał się wyboru cara, H. Biaudet, Les origines..., s. 53 -54; H. Almquist, Den politiska..., s. 59-61, 168-169; K. Lepszy, Walka stronnictw..., s. 55-57. Przeświadczenie historyków o tym, że Jan III zdecydował się wysłać syna do Polski w obawie przed wyborem cara pokutuje do dziś w historiografii; kwestia ta jest złożona, 
Tymczasem szwedzki monarcha po pomyślnym dlań rozstrzygnięciu konfliktu z bratem na riksdagu tylko czekał na kolejnego posła z Polski. Pod koniec stycznia 1587 roku do Vadsteny dotarł pierwszy wysłannik królowej a 10 (1) marca $^{28}$ Jan III napisał w liście do Anny I, że zgadza się na forsowanie kandydatury syna na tron jego przodków. Jedyne, o co prosił to, aby królowa przy układaniu Paktów konwentów nie dopuściła do rzeczy niemożliwych do spełnienia ${ }^{29}$.

Kandydatura Zygmunta miała ogromne szanse powodzenia. Była możliwa do zaakceptowania przez obydwa narody Rzeczypospolitej. Wyniesienie na tron Jagiellona po kądzieli miało zakończyć również wysuwane przez Sztokholm w jego imieniu pretensje do tronu wielkoksiążęcego:

Ustałyby też pretensje albo prawa, które królewicz szwedzki [ma] na Litwę [...] jako na państwo dziedziczne po matce swej, co samo kiedykolwiek mogłoby sprawić wielkie zamieszanie między temi dwiema królestwami ${ }^{30}$.

bo dla pozyskania szwedzkiej opinii publicznej Jan III rzeczywiście mógł szermować takim argumentem i udawać, że wierzy w realność takiego szantażu. W rzeczywistości jednak ani on, ani wytrawni dyplomaci szwedzcy nie mogli bać się wyboru cara, gdyż doskonale zdawali sobie sprawę, że Fiodor I nie miał żadnych szans na koronę polską, nie spełniał wszak podstawowych wymogów, jakie szlachta polsko-litewska stawiała kandydatowi do tronu. Po pierwsze, był wyznawcą prawosławia i to fanatycznym, którego wyboru prymas-interreks nigdy by nie ogłosił, nie wspominając już o koronacji na Wawelu. Po drugie, nie było mowy, by miast na Kremlu, zamieszkał na stałe w Polsce. Po trzecie, był niedorozwinięty umysłowo i niezdolny do sprawowania rządów nawet we własnym państwie. Po czwarte, Moskwa była wówczas poważnie skonfliktowana z Koroną i Litwą o Inflanty i dostęp do Bałtyku, o ziemie ruskie oraz o tytuł carski, którego w Rzeczypospolitej nie uznawano, P. Szpaczyński, [Recenzja] W. Leitsch, Sigismund III. von Polen und Jan Zamoyski. Die Rolle Estland in der Rivalität zwischen König und Hetman, Verlag der Österreichischen Akademie der Wissenschaften, Wien 2006, ss. 289, [w:] In gremium, t. 3: Studia nad historia, kultura. i polityka, red. D. Dolański, B. Nitschke, Zielona Góra 2009, s. 127.

${ }^{28}$ Pierwsza data według tzw. nowego stylu - kalendarza gregoriańskiego obowiązującego w Polsce, druga zaś według tzw. starego stylu - kalendarza juliańskiego obowiązującego w Szwecji.

${ }^{29}$ Jan III do A. Jagiellonki, Vadstena, 1 III 1587, Dodatki, nr 6, [w:] H. Biaudet, Les origines..., s. 65-67.

30 „Zdanie dyskursem wyrażone, kto by miał być obrany królem w Polsce po zejściu Najjaśniejszego Stefana Batorego króla polskiego", Biblioteka Czartoryskich [dalej: 
Nie tylko przeciw Habsburgom, ale i przeciw carowi zwolennicy kandydatury Zygmunta trafili z argumentacją wskazując, że: „Turek jako z Jagiełłową krwią sancte pokój trzymał, tak by i z nim czynił”31. Tym bardziej, że czausz Mustafa, który przybył do Warszawy 19 marca 1587 roku, nie ukrywał, że w Stambule z radością powitanoby wybór któregoś z własnych lenników - bratanków Batorego, bliżej nieokreślonego „Piasta” - jednego z polskich magnatów lub królewicza szwedzkiego ${ }^{32}$.

Czart.], Teki Naruszewicza [dalej: TN] 92, s. 99. Wiosną 1582 r. Jan III przypomniał posłom Rzeczypospolitej w Sztokholmie o dziedzicznych prawach Zygmunta do wielkoksiążęcego tronu Litwy, kwestionując po raz kolejny zmianę owego tronu z dziedzicznego na obieralny, dokonaną przez Zygmunta II Augusta 13 marca 1564 r.: „Synowie moi są dziedzicami Litwy [...] nie ma Litwa wolnej elekcji”, Relacya legacyi Pana Kuchmistrza Posta Króla Polskiego do Szwedzkiego Króla, [w:] Sprawy wojenne króla Stefana Batorego. Dyjaryjusze, relacje, listy $i$ akty z lat 1576-1586, wyd. I. Polkowski, Kraków 1887, s. 367. O pretensjach króla szwedzkiego do Inflant i Litwy jako dziedzicznego państwa Jagiellonów, zob. też: O bezkrólewiu po śmierci Stefana Batorego przez Horacyusza Spanocchi sekretarza kardynata Bolognetto, nuncjusza $w$ Polsce w ostatnich latach panowania tego króla, [w:] Relacje nuncjuszów apostolskich i innych osób o Polsce od roku 1548 do 1690, wyd. E. Rykaczewski, t. 1, Berlin-Poznań 1864, s. 468; E. Tyszkiewicz, „Stefana Batorego rokowania ze Szwedami w 1582 roku", Wilno 1872, maszynopis, Biblioteka Polskiej Akademii Umiejętności i Polskiej Akademii Nauk w Krakowie [dalej: PAU i PAN], sygn. 2523; H. Almquist, Johan III och Stefan Batori år 1582, „Historisk Tidskrift” 1909, s. 93-122; W. Nowodworski, Stosunki Rzeczypospolitej ze Szwecja i Dania za Batorego, „Przegląd Historyczny" 1911, t. 12, s. 11-30, 165-184, 308-324.

31 Wotum kasztelana sochaczewskiego [Stanistawa Gostomskiego], „Ratie pro electione Zygmunta królewicza", Biblioteka Zakładu Narodowego im. Ossolińskich we Wrocławiu, rkps 2284, k. 9.

32 Dyaryusze sejmowe, R. 1587, s. 34; H. Wisner, Dyplomacja polska w latach 15721648, [w:] Historia dyplomacji polskiej, t. 2: 1572-1795, red. Z. Wójcik i M. Biskup, Warszawa 1982, s. 71; „Kopia odpisu na list baszy tureckiego od PP Rad podczas interregnum po królu Stefanie, w którym liście basza napominał, aby tego za króla obrali, kogo oni popierają", Biblioteka im. Raczyńskich w Poznaniu, rkps 27, k. 88-88 v; por.: „Odpowiedź panów rad koronnych i litewskich na odezwę Amurata III (Murad III 1546-1595, panował od 1574), sułtana tureckiego", 30 IV 1587, AGAD, Archiwum Radziwiłłów, dz. II, nr 180. Zygmunta polecano w nadziei, że przesunie punkt ciężkości polityki zagranicznej Rzeczypospolitej na północny wschód, a Turcja zyska przy okazji sojusznika przeciw Rosji. O tym, że z tych samych względów w poprzednich bezkrólewiach zalecano króla Szwecji Jana III, K. Olejnik, Stefan Batory, s. 49. 
Po Piaście pożyteczniejszego nad Królewicza J. Mści Szwedzkiego, najbliższego człowiekowi narodu swego być nie baczy, którego powinniśmy to wedle sprawiedliwości, choć mamy liberum electionem ${ }^{33}$.

W tym duchu wypowiedziała się zdecydowana większość panów koronnych na sejmie elekcyjnym. Niektórzy, jak związany z królową kasztelan sochaczewski Stanisław Gostomski, utożsamiali Zygmunta z Piastem: „Do królewicza JMści szwedzkiego przystępuję, którego też za Piasta rozumiem" "34. Większość zaś przyznawała, że jest on najbliższy Piastowi. Niektórzy, jak Konstanty Wiśniowiecki (1564-1641), traktowali siostrzeńca Zygmunta II Augusta wprost jako jego syna:

Otóż mamy królewicza JMści szwedzkiego, którego ja tak poczytam, jakoby miał być króla Augusta synem albo Janem królewiczem węgierskim $^{35}$, o którym mawialiśmy: to byłby jako nasz, kiedy był żyw, bo także jest rodzonym siostrzeńcem nieboszczyka jako ten ${ }^{36}$.

Obok oczywiście bliskiego pokrewieństwa z Jagiellonami, koronnym argumentem królowej przemawiającym na korzyść Zygmunta, była tak ważna w polityce jej ojca, a zwłaszcza brata, kwestia bałtycka:

Wiedzą W. M. jako wiele na tem zależy liberum dominium maris, bez którego słabe są największe państwa, a najmniejsze państwo morską wolnością i państwem portów ku górze się wynosi ${ }^{37}$.

Królowej wtórowali zwolennicy kandydatury jej siostrzeńca, wskazując na współdziałanie w kontroli nad handlem Moskwy z Zachodem:

33 Wotum wojewody ptockiego [Grzegorza Zielińskiego], 14 VIII 1587, [w:] Dyaryusze sejmowe, R. 1587, op. cit., s. 98-99.

34 Wotum kasztelana sochaczewskiego [Stanistawa Gostomskiego], ibidem, s. 100-101.

35 Jan (II) Zygmunt (1540-1571), syn córki Zygmunta I, Izabeli (1519-1559) i króla węgierskiego Jana Zapolyi (1487-1540, panował od 1526), por.: Królowie węgierscy z Domów: Arpadów, Anjou, Hunyady i Zapolya, [w:] Genealogia - Tablice, op. cit., nr 85.

36 Wotum K. Wiśniowieckiego na elekcji 1587, [w:] Dyaryusze sejmowe, R. 1587, op. cit., s. 106.

37 Królowej Anny..., op. cit., s. 313. 
Moskwę nie jedno morzem, ale Finlandią otoczym, zagrodzim, ich towary przez naszych kupców ręce i z naszym pożytkiem iść muszą

i na przerwanie kontaktów dyplomatycznych Kremla z nieprzyjaznymi Rzeczypospolitej potęgami w Europie, zwłaszcza Habsburgami:

Odrazim ich od porozumienia z inszymi pany chrześcijańskimi, których $\mathrm{z}$ dawna na zgubę i zgubienie nasze morzem sięgali ${ }^{38}$.

Wskazywano również na możliwość skuteczniejszego prowadzenia wojny z Rosją zgodną z oczekiwaniami Szwedów-Finów i interesem Rzeczypospolitej: „z Moskwą wojna potężniejsza, bo ze dwiema walczyć by wiele na nią było" 39 . Zwracano uwagę, na korzystny moment wspólnego sojuszu:

za złączeniem sił [...] lepiej by się i szczęśliwiej mogła prowadzić wojna w Moskwie, Moskwa teraz dla niezgod domowych w wielkim jest zamieszaniu.

Konkluzja autora Zdania dyskursem wyrażonego... wprost korespondowała z imperialnymi dążeniami Zygmunta III i jego ojca Jana III:

Nie rozumiem, jakiego by sobie Króla pożyteczniejszego miała szukać ta Rzeczpospolita chrześcijańska nad niego, który gdy dostanie Moskwy, przejdzie możnością i zjednoczeniem państwa wszystkie insze pany europejskie ${ }^{40}$.

Walka o władzę w Rosji istotnie wydawała się doskonałym momentem do realizacji planów Stefana I Batorego ${ }^{41}$. Były minister zmarłego króla, Jan Zamoyski, grający przysłowiowe pierwsze skrzypce w Koronie,

38 Ratie pro electione..., op. cit., k. 13.

39 „Commoda do uwagi podane któryby były dla Rzptej z obrania Królewicza Szwedzkiego na Tron Polski”, Czart., TN 92, s. 836; druk [w:] E. E. Mayer, Des Olmützer..., s. 33-36.

${ }^{40}$ Zdanie dyskursem..., op. cit., s. 691-693.

41 W. Baranowski do S. Reszki, Grodno, 10 II 1589, BJ, rkps 1133, k. 18-20. 
nie myślał jednak o antyrosyjskim sojuszu ze Szwecją. On sam chciał być królem ${ }^{42}$. I choć nie miał odwagi wysunąć swojej kandydatury, gdyż jego klientela nie kwapiła się, aby uczynić to za niego, usiłował pomieszać szyki Jagiellonce, pozorując zgodę na wybór Zygmunta i wymuszając na szwedzkich posłach zgodę na warunek nie do przyjęcia - inkorporację szwedzkiej Estonii do Polski w zamian za wybór Jagiellona po kądzieli na tron polski ${ }^{43}$. W dodatku wykreślił z przywiezionego przez nich konceptu przyszłego związku królestw najważniejszy, z punktu widzenia Jana III,

${ }^{42} \mathrm{O}$ tym, że Zamoyski chciał zostać królem, zob.: A. Prochaska, Sejmiki wiszeńskie w czasach trzech pierwszych elekcji pojagielloniskich, KH 1903, t. 17, s. 578; J. Schweizer, Die Sukccesionsvirren in Polen (1586-1589), [w:] Nuntiaturberichte aus Deutschland nebst ergänzenden Aktenstücken 1585 (1584-1590), Zweite Abteilung: Die Nuntiatur am Kaiserhofe. Zweite Hälfte: Antonio Puteo in Prag 1587-1589, Hrsg. J. Schweizer, Paderborn 1912, s. XV; J. A. Chrościcki, Czy można nazwać mecenasami polskich Wazów?, [w:] Tryumfy i porażki, red. M. Bogucka, Warszawa 1989, s. 191-192; J. Besala, Stanistaw Żótkiewski, Warszawa 1988, s. 160; K. Haselbach, Österreich und die polnische Königswabl..., s. 16; Ł. Żłobińska, Propaganda morska..., s. 114, 128; W. Kaczorowski, Bitwa pod Byczyna, Opole 1988, s. 9; L. Bazylow, Siedmiogród a Polska 1576-1613, Warszawa 1967, s. 44; W. Czapliński, Zarys dziejów Polski do roku 1864, Kraków 1985, s. 230-231. K. Lepszy wskazywat, że Zamoyski przed przybyciem Zygmunta do Polski potajemnie przygotowywał kandydaturę Andrzeja Batorego (zm. 1598), sam - według K. Lepszego - nie chciał, gdyż wcześniej szukał Piasta, K. Lepszy, Walka stronnictw..., s. 43-45, 100; S. Grzybowski, Jan Zamoyski, Warszawa 1994, s. 195-202; H. Wisner jednak zauważył, że kandydaci, jakich proponował kanclerz Zamoyski - Joachim Osiecki czy Jan Ostroróg (1565-1622) wskazywali na niego, H. Wisner, Zygmunt III Waza, wyd. 2, Wrocław-Warszawa-Kraków 2006, s. 51; W. Leitsch uznał, że Zamoyski tolerował wybór Zygmunta z jednej strony $\mathrm{w}$ nadziei, że nie przyjedzie, z drugiej, aby militarnie rozprawić się ze zwolennikami Habsburga i w korzystnym dla siebie momencie wystąpić z własną kandydaturą, W. Leitsch, Sigismund III..., s. 57-58, 62-65, 121-124, 257-259; por.: J. Dzięgielewski, Jana Zamoyskiego..., s. 81-88.

${ }^{43} \mathrm{~K}$. Lepszy twierdził, że Zamoyski wymusił inkorporację, ponieważ było to żądanie szlachty, K. Lepszy, Walka stronnictw..., s. 9, 32-33, 56; W. Leitsch jest odmiennego zdania, dowodząc, że Estonia odgrywała znikomą rolę w propagandzie na rzecz Zygmunta i w wotach nawet nikt o tym nie wspominał, a Zamoyskiemu, który wymusił na szwedzkich posłach przekroczenie uprawnień nie chodziło o Estonię, ale o przeszkodzenie Zygmuntowi w przybyciu na koronację i rozstrzygnięcie wydarzeń po swojej myśli, W. Leitsch, Sigismund III..., s. 118-119, 122-123. Tezę W. Leitscha potwierdza Anna Pieńkowska, autorka najnowszego opracowania dotyczącego bezkrólewia po śmierci Stefana Batorego, A. Pieńskowska, Zjazdy i sejmy..., s. 380. 
punkt o wspólnej wojnie i wiecznym sojuszu przeciw Moskwie ${ }^{44}$. Wówczas Anna I okazała się nieodrodną córką swojej matki, królowej Bony Sforzy, wykazując więcej sprytu niż mistrz propagandy i doktor obojga praw Jan Zamoyski, któremu z wielką zręcznością dyplomatyczną narzuciła kandydaturę siostrzeńca ${ }^{45}$. Jej postawę po śmierci Batorego nie bez przyczyny złośliwie zrymowano: „Długoć się nam aniołem Anuchna stawieła, Ale się na ostatku w czarta obrócieła" ${ }^{4}$. Poręczyła mianowicie zwrot szwedzkiej części Estonii całym swoim majątkiem ${ }^{47}$, co pozwoliło Szwedom na zręczne wycofanie się ze złożonej wcześniej w Polsce obietnicy ${ }^{48}$. Królowa nie przejmowała się wykreśleniem punktu o wspólnej wojnie z Moskwą, wszak w paktach konwentach przyszłego króla zobowiązano tradycyjnie do odzyskania awulsów - ziem utraconych niegdyś przez państwo polsko-litewskie ${ }^{49}$. A że wśród nich przede wszystkim widniały Czernihowszczyzna, Siewierszczyzna i Smoleńszczyzna [utracone za stryja Anny I - Aleksandra I (1461-1506, książę litewski od 1492, król Polski od 1501) oraz za jej ojca Zygmunta I (1467-1548, panował od 1506 roku)], to konfrontacja zbrojna z Moskwą stawała się de facto nieunikniona. Wykreślenie punktu wprost mówiącego o wspólnej wojnie dało się też z łatwością wytłumaczyć chęcią nieeskalowania napięcia z Moskwą, która, zdając sobie sprawę z po-

44 Oratio, quam nomie Ioannis tertii, Sueciae regis, magister Georgius Palmerius Stockholmensis stando recitavit, [w:] E. E. Mayer, Des Olmützer..., s. 354; zob.: instrukcję dla posłów, którą przywieźli ze Szwecji, „Conditiones, quas ser. princeps Sigismundus Svetiae rex designatus offert Polonis, si in regem Poloniae electus fuerit”, Czart., TN 92, s. 427-430; pacta conventa o odzyskaniu awulsów, ale z brakiem wyraźnego zapisu o sojuszu, Volumina Legum. Przedruk zbioru praw staraniem XX pijarów w Warszawie, od roku 1732 do roku 1782, wyd. J. Ohryzko, Petersburg 1859, s. 247-248.

45 W. Sobieski, K. Lepszy, Anna Jagiellonka, [w:] PSB, t. 1, Kraków 1935, s. 131.

46 Okolicznościowa poezja polityczna w Polsce. Zygmunt III, wyd. J. Nowak-Dłużewski, Warszawa 1971, s. 45.

47 Poręczenie królowej, [w:] Volumina Legum..., t. 2, s. 247.

48 Podkanclerzy Eryk Larsson Sparre (1550-1600), który przekroczył w czasie elekcji swoje uprawnienia oświadczył, że punkt o Estonii tak naprawdę nie jest wiążący, skoro królowa Anna I Jagiellonka poręczyła jego wykonanie całym swym majątkiem. W. Leitsch. zastanawia się, czy rzeczywiście było jakieś ustne zastrzeżenie w tej kwestii, czy też Sparre okłamał króla Jana III, aby przełamać jego opór, zob.: W. Leitsch, Sigismund III..., s. 125.

49 Pacta conventa, [w:] Volumina Legum, t. 2, s. 247-248. 
wagi sytuacji, była wystarczająco przerażona perspektywą unii Polski-Litwy z Szwecją-Finlandią. Posłowie moskiewscy, którzy przybyli na elekcję, aby wystawić kandydaturę cara, bynajmniej nie ukrywali, „iż królestwo rozdwojone przyjąć chcą zwłaszcza przeciw Szwedowi”"50.

Anna I nie ukrywała swoich planów dynastycznych wobec stronników Zamoyskiego, dopytujących się natarczywie z polecenia swego protektora, kogo wybrać, gdyby Zygmunt jednak nie przybył na koronację. Gdyby tak się stało, to w grę - według Anny I - wchodził każdy kandydat, nawet stanowiący dla Zamoyskiego największe zagrożenie arcyksiążę Maksymilian Habsburg, popierany przez pałające żądzą odwetu na kanclerzu za „tyraństwo” Batorego stronnictwo Zborowskich, pod warunkiem jednak, że poślubi młodszą siostrę Zygmunta, a jej siostrzenicę i imienniczkę Annę $(1568-1625)^{51}$. Królowej chodziło przede wszystkim o to, aby w żyłach przyszłych królów polskich płynęła krew Jagiellonów, a tym samym, aby została zapewniona ciągłość dynastyczna.

Arcyksiążę Maksymilian przystał od razu na małżeństwo ze szwedzką królewną ${ }^{52}$, Zamoyski tymczasem postanowił - po odparciu szturmu Habsburga na stołeczny Kraków, w ciągłej nadziei, że Zygmunt jednak nie przybędzie ${ }^{53}$ - przeforsować z pomocą wrogiej Habsburgom Turcji,

50 Wypisy należace do Moskwy z Diariusza Elekcji Zygmunta III króla Polski 1587, [w:] Historica Russiae Monumenta, изд. А. И. Тургенев, т. 2: Акты исторические относящиеся к России, С. Петерсбург 1842, nr 15, s. 20. Przybyli na elekcję posłowie moskiewscy wprost zagrozili „Jeśli Szweda będzie mieć za pana, my zaraz na konie swe wsiadamy przeciw wam [...] rozlanie krwi wieczne między nami nie ustanie", Stuchanie postów cudzoziemskich, 20 VIII 1587, [w:] Dyaryusze sejmowe, R. 1587, op. cit., s. 213.

${ }^{51}$ K. Lepszy, Wróg Habsburgów - Jan Zamoyski, „Roczniki Historyczne” 1949, R. 18, s. 132-133.

52 Arcyks. Maksymilian do Anny Jagiellonki, Wien, 17 VI 1587, Czart., TN 92, s. 257-258; G. Kurkowska, Anna Wazówna (1568-1625). Polskie losy szwedzkiej królewny, Toruń 1995, s. 19.

53 W wotum na elekcji, opowiadając się za „Piastem”, kanclerz koronny ani słowem nie wspomniał o potomku Jagiellonów: Wotum J. Zamoyskiego, [w:] Dyaryusze sejmowe, R. 1587, op. cit., s. 103. Nie był też obecny przy nominacji Zygmunta, nie podpisał sporządzonego aktu elekcji ani recesu sejmu elekcyjnego. O wahaniach Zamoyskiego w kwestii wyboru Zygmunta zob.: R. Heidenstein, Dzieje Polski od śmierci Zygmunta Augusta do roku 1594 ksiag 12, tłum. z łac. J. M. Gliszczyński, t. 1-2, Petersburg 1857, s. 236-243. Zachowanie Zamoyskiego wywołało od razu liczne podejrzenia, o czym zob.: 
Tatarów i Siedmiogrodu ${ }^{54}$ kandydaturę stryjecznego brata swej żony, Andrzeja Batorego (1563-1599) ${ }^{55}$. Ten ostatni miał zadeklarować, że ożeni się ze szwedzką królewną ${ }^{56}$, gdyż tego oczekiwała Anna I Jagiellonka od przyszłego króla Polski w przypadku nieprzybycia Zygmunta. Jej stanowiska w tej sprawie nie sposób było zlekceważyć57. Królowa-wdowa i król w jednej osobie miała nie tylko pieniądze, których - zwykle oszczędna teraz nie żałowała, aby przekonywać mniej przekonanych do kandydatury swego siostrzeńca. Miała również za sobą wielu Litwinów, niemal cały senat, zwłaszcza episkopat, a nawet papieża Sykstusa V (Felice Peretti, 1520-1585, papież 1585-1590), uważanego niesłusznie za zwolennika Habsburga. Papież, ubolewając nad śmiercią Batorego, planującego wielką wyprawę przeciw Turcji, akurat wtedy, gdy ważyły się losy polskiej korony

Annibale di Capua do kard. Montalto [A. Peretto], Warszawa, 4 VIII 1587, PAU i PAN, Teki Rzymskie [dalej: TR] 42, k. 365-368. Konsekwentnie, Zamoyski nie podpisał też uniwersału wiślickiego zatwierdzającego elekcję Jagiellona po kądzieli, Poparcie wolney elekcji Króla Zygmunta Trzeciego polskiego y szwedzkiego na zjeździe pod Wiślica namówione, [w:] Volumina Legum..., t. 2, s. 243-245; K. Lepszy, Walka stronnictw..., s. 42, 48-49.

${ }^{54}$ Dlatego też zadbał, by przekazano nuncjuszowi papieskiemu Annibalowi di Capua (1544-1594), że raczej wezwie na pomoc Turcję. niż dopuści do koronacji Habsburga, Annibale do kard. Montalto, Warszawa, 30 VIII 1587, TR 42, k. 378-379; J. Sas, Stosunki polsko-tureckie w pierwszych latach Zygmunta III, „Przegląd Powszechny” 1897, t. 55, s. 114.

$55 \mathrm{~J}$. Zamoyski wysondował wcześniej wprawdzie, że Batory nie ma poparcia zob.: J. Zamoyski do M. K. Radziwitta, kasztelana trockiego, Zamość, 25 V 1587 r., [w:] Archiwum Jana Zamoyskiego kanclerza $i$ hetmana wielkiego koronnego, t. 4: 1585-1588, wyd. K. Lepszy, Kraków 1948, s. 122 - liczył jednak, że wobec nieprzybycia Zygmunta, gdy alternatywą będzie „czyhający na szlachecką wolność” Habsburg, magnaci przychylni Jagiellonowi po kądzieli wraz z tłumami szlachty nie będą mieli wyjścia. Podejrzeń w związku z tym nie brakowało również w otoczeniu Zamoyskiego, o czym świadczą zapisy w diariuszu przychylnego kanclerzowi opata jędrzejowskiego Stanisława Reszki (1544-1600). On również wspomina o potajemnych rozmowach, które kanclerz prowadził w Krakowie z bratankiem króla Batorego, kardynałem Andrzejem, Stanislai Rescii diarium 1583-1589, red. J. Czubek, Kraków 1915, s. 155, 158.

${ }^{56}$ A. Puteo do kard. Montalto, Praga, 19 IX 1587, [w:] Nuntiaturberichte..., nr 45.

${ }^{57} \mathrm{O}$ tym, że królowa Anna w trzeciej elekcji była „uznanym i aktywnym autorytetem" zob.: J. Szujski, Ostatnie lata Zygmunta Augusta i Anna Jagiellonka, [w:] idem, Dzieta, Seria 2, t. 6, Kraków 1885, s. 321. 
postanowił obdarować królową Annę I najwyższym oznaczeniem - Złotą Różą ${ }^{58}$.

Ostatniego dnia obrad sejmu elekcyjnego, w środę 19 sierpnia 1587 roku o godzinie pierwszej po południu, prymas Stanisław Karnkowski (1520-1603) w okolicach podwarszawskiej Woli, zgodnie z wolą przeważającej większości szlachty koronnej, mianował Zygmunta królem Polski i wielkim księciem Litwy. Nieobecność Litwinów, zgodnie z aktem unii lubelskiej, nie mogła podważyć ważności elekcji ${ }^{59}$. Nastroje panujące jednak w Wielkim Księstwie trafnie oddają słowa kasztelana trockiego i zwolennika Habsburgów, Mikołaja Krzysztofa Radziwiłła „Sierotki” (1549-1616), który wprost przyznał, że Litwini: „postawą tylko snadź się gniewają, a sercem wielkie ofiarowania królowej uczynili” ${ }^{60}$. Wtórował mu wojewoda trocki Jan Hlebowicz (zm. 1590), gdy wprost powiedział:

58 W czasie bezkrólewia po śmierci Stefana I Batorego ze względu na problem turecki bez wątpienia najbardziej pożądanym przez kurię rzymską władcą państwa polsko-litewskiego mógł się wydawać jeden z arcyksiążąt habsburskich. Doświadczenia z poprzednich elekcji dowiodły jednak, że - jak to ujął Orazio Spanocchi, sekretarz kardynała Alberto Bolognetti (1538-1585), nuncjusza w Polsce w ostatnich latach panowania króla Stefana I Batorego (do maja 1585): „niewielka skłonność Polaków do narodu niemieckiego może nam być rękojmią, że żaden nawet książę niemiecki wezwany nie będzie”. Największe szanse jego zdaniem miał królewicz Zygmunt, który: ,jak się zdaje będzie prędzej niż kto inny wybrany [...] pierwsza i najgłówniejsza przyczyna, że jest ostatnim potomkiem familii jagiellońskiej”. Podkreślał nawet, że szlachta: „powinna powołać na tron królewicza Zygmunta jako prawdziwego potomka Jagiellonów”. Wyrażał nadzieję, że tak się właśnie stanie: „mam nadzieję, że jego elekcja przyjdzie do skutku”. Co do Turcji, to sekretarz kardynała wskazywał na potęgę Zygmunta III jako władcy Rzeczypospolitej i Szwecji, państw, które wspólnie miały dokonać podboju Moskwy: „Siły tego króla [...] może nawet same zdołają trzymać na wodzy potęgę Otomańską i jej skutecznie zagrozić”, O bezkrólewiu..., op. cit., s. 467-471. O tym, że papież Sykstus V sprzyjał od początku elekcji Zygmuntowi a nie Habsburgom zob.: R. Hassencamp, Papst Sixtus..., s. 49-68; por.: H. Biaudet, Sixte Qiunti..., s. 17-19.

59 Akta unji Polski z Litwa (1585-1791), wyd. S. Kutrzeba, W. Semkowicz, Kraków 1932. O postawie Litwinów zob.: Annibale di Capua do kard. Montalto, Warszawa, 4 VII i 22 VII 1587, Listy Annibala..., op. cit., s. 54-60, 62-65; R. Heidenstein, Dzieje Polski..., s. 226. O urazach litewskich zob. też: J. Bielski, Dalszy ciag Kroniki Polskiej, zawierajacy dzieje od 1587 do 1598 r., wyd. F. M. Sobieszczański, Warszawa 1851, s. 20.

${ }^{60}$ M. K. Radziwiłł do K. Radziwiłła, Nieśwież, 12 IX 1587, ADR, s. 34-35. 
To jedno nam remedium tych żalów naszych, że widzimy ich króla ze krwi naszej pochodzącego [...], by nie Królowa, potomek Jagiełłowski, poznalibyście to, że się umie Litwa gniewaćc ${ }^{61}$.

Anna I Jagiellonka, która chciała i żądała, aby Zygmunt został królem Polski, wzruszona do łez odśpiewała uroczyste Te Deum w kolegiacie św. Jana wraz z prymasem, który, ogłaszając wybór jej kandydata, mówił: „widzę, że to jest wola Boża, a zezwolenie Wszech WM, aby był Panem naszym Królewicz JM. Szwedzki" ${ }^{62}$. Ci, którzy 22 sierpnia, trzy dni po zakończeniu obrad sejmu, wybrali arcyksięcia Maksymiliana, nabożeństwo dziękczynne zmuszeni byli odprawić w podwarszawskim kościele bernardynów, gdyż oburzona Jagiellonka na wieść o podwójnej elekcji rozkazała zamknąć przed nimi bramy Warszawy ${ }^{63}$. Walka o tron dla siostrzeńca była przejawem dynastycznej polityki Anny I Jagiellonki, która uważała się za kontynuatorkę dynastii, a Zygmunta - „ostatnią latorośl” - za jej przedstawiciela i sukcesora. Anna I nie miała poczucia, że dynastia Jagiellonów wygasła w 1572 roku z chwilą śmierci jej brata. Po wyborze Zygmunta wprost pisała w rozsyłanych przez siebie listach po kraju: „Przy krwi naszej Jagiełłowskiej statecznie stać będziecie" ${ }^{64}$.

Po elekcji królowa, w której imieniu posłowie wysłani do cesarza mieli podkreślić, że Zygmunta wybrano jako Jagiellona po kądzieli, radziła szukać zgody przez małżeństwo arcyksięcia Maksymiliana z siostrą Zygmunta Anną, która miała z nim przybyć ze Szwecji ${ }^{65}$. Najmłodszy z Habsburgów od początku swych starań o koronę zapewniał o gotowości poślubienia szwedzkiej królewny. Jeszcze na początku maja 1587 roku z inicjatywy arcyksięcia Maksymiliana wyruszyło w tej sprawie do Szwecji poselstwo,

${ }^{61}$ Dyaryusze sejmowe, R. 1587, s. 141; por. J. Bielski, Dalszy ciag..., s. 57-59, 61. O tym, z czym owe gniewy były związane zob.: H. Lulewicz, Gniewów o unię..., s. 378 -396; T. Kempa, Plany separatystycznej elekcji..., s. 53-59.

${ }^{62}$ Dyaryusze sejmowe R. 1587, op. cit., s. 129.

${ }^{63}$ M. Bogucka, Anna Jagiellonka..., s. 145.

${ }^{64}$ A. Jagiellonka do Akademii Wileńskiej, Warszawa, 24 VIII 1587, [w:] Jagiellonki polskie..., t. 4, s. 309.

${ }^{65}$ A. Jagiellonka do arcyks. Maksymiliana, Warszawa, 28 VIII 1587, Czart., rkps 2254, k. 20-21. 
któremu przewodził Felix Herberstein (zm. 1605) ${ }^{66}$. W czerwcu Habsburg poinformował o swych zamiarach królową Annę I Jagiellonkę, która, na wypadek gdyby Zygmunt i jego ojciec odmówili przyjęcia korony, gotowa była - jak wspomniano - forsować kandydaturę arcyksięcia pod warunkiem, że poślubi jej siostrzenicę ${ }^{67}$.

Wbrew wszelkim pogłoskom o trudnościach, jakie napotkali posłowie Rzeczypospolitej, którzy po elekcji przybyli po Zygmunta do Szwecji, Anna I Jagiellonka przez cały czas rozpowszechniała informacje, że Zygmunt już wypłynął z Kalmaru i że w każdej chwili należy spodziewać się jego przybycia pod Wawel. Kiedy wreszcie Zygmunt wraz z młodszą siostrą Anną przybył do Polski na koronację, dzień 4 listopada 1587 roku, w którym Jagiellonka spotkała w Piotrkowie dzieci swej zmarłej siostry - „pana synaczka” „Zysia” i „Janusię” - był jednym z najszczęśliwszych w jej życiü ${ }^{68}$. Dnia 9 grudnia 1587 r. orszak króla-elekta dotarł do Krakowa. Pod murami Kazimierza, biskup kamieniecki Wawrzyniec Goślicki (ok. 1530-1607) ${ }^{69}$, znany Zygmuntowi z poselstwa do Szwecji za panowania Batorego, powitał go słowami: „Przyjechać raczyłeś swój między swe. Gościem tu nie jestes””. Hierarcha podkreślał, że Zygmunt, jako Jagiellon po kądzieli, ma specjalne uprawnienia do tronu Rzeczypospolitej. Przypominał, że w Krakowie urodziła się jego matka Katarzyna. Na każdym kroku akcentowano związek kró-

${ }^{66}$ S. Cynarski, Uwagi w sprawie kandydatury habsburskiej w czasie pierwszych elekcji w Polsce, „Śląski Kwartalnik Historyczny Sobótka” 1992, t. 47, nr 1-2, s. 68.

${ }_{67}$ Arcyks. Maksymilian do Anny Jagiellonki, Wien, 17 VI 1587, Czart., TN 92, s. 257-258; G. Kurkowska, Anna Wazówna..., s. 19.

${ }^{68}$ Dnia 28 IX 1587 r., flotylla szwedzka z królem-elektem Zygmuntem na czele osiągnęła Hel. Szczegóły podróży od przybycia do wjazdu do Krakowa zob.: Przyjazd Króla JM Zygmunta, 29 IX-9 XII 1587, Biblioteka Narodowa [dalej: BN], rkps 6610, k. 42 v-46 v; R. Heidenstein, Dzieje Polski, s. 270-271. Po koronacji Zygmunta III królowa Anna I w nagłówku listów pisała: „Najjaśniejszy Miłościwy Królu, Panie Siostrzeńcze, Synu nasz najmilszy", [w:] Jagiellonki polskie..., t. 4, s. 320-330; podpisywała je zaś własnoręcznie: „Życzliwa ciotka i matka, Anna królowa polska”, AGAD, dz. I (Zbiór dokumentów pergaminowych), nr 883.

69 D. Maniewska, Goślicki Wawrzyniec, [w:] PSB, t. 8, Wrocław 1959-1960, s. 379-382 . 
la-elekta z dynastią jagiellońską ${ }^{70}$. Wśród portretów Jagiellonów zdobiących trasę przejazdu ich potomka przez Kraków na Wawel wyróżniał się wizerunek Aleksandra I Jagiellończyka, który pod koniec XV wieku wystąpił z projektem przyznania sobie szwedzkiej korony a po uzyskaniu tronu polskiego wysunął kandydaturę swego młodszego brata Zygmunta - w 81. rocznicę jego śmierci wybrano Zygmunta III na tron polski. Dziadkowi Zygmunta III ze strony matki jeszcze w 1520 roku jedno ze stronnictw szwedzkich oferowało koronę Szwecji ${ }^{71}$. Dla ciepłego przyjęcia nie bez znaczenia pozostawał fakt, że Zygmunt, w odróżnieniu od swych dwóch cudzoziemskich poprzedników, przemawiał po polsku. Walka o tron dla Zygmunta była walką o Polskę jagiellońską a potomek Jagiellonów, będący jednocześnie szwedzkim dynastą i dążący do podporządkowania sobie Rosji, miał niepowtarzalną szansę na powtórzenie - i to na znacznie większą skalę - fenomenu jagiellońskiego sprzed wieku, kiedy to przedstawiciele polsko-litewskiej dynastii zasiadali równocześnie na czterech tronach Europy ${ }^{72}$.

Bezceremonialne ultimatum kanclerza Zamoyskiego na posiedzeniu rady senatu podczas sejmu koronacyjnego, „Jeżeli Wasza Królewska Mość [...] taki masz wstręt do ustąpienia Estonii, pozwól a przystąpimy do obrania innego pana"73, świadczy o tym, że pierwszy minister w Koronie ciągle jeszcze walczył o swego kandydata, który dokończy to, czego nie zdążył Stefan I - utoruje mu drogę do tronu Jagiellonów. Usiłował więc poprzez wspomniane ultimatum odprawić Zygmunta z powrotem, jednak szlachta nie była gotowa na to, aby wszystko zaczynać od początku ${ }^{74}$. Butny minister dał upust swemu niezadowoleniu w słowach wypowiedzianych do Marcina

70 Witanie Rad i Stanów Koronnych polskich do Króla J. Mści Zygmunta III..., uczynione, [w:] Wybór mów staropolskich, oprac. A. Małecki, Kraków 1860, s. 107-114; zob. też: „Witanie poselskie Króla JM przez Świętosława Orzelskiego z Orla, sędziego ziemskiego kaliskiego", BN, rkps 6610, k. 46 v-48.

${ }^{71}$ H. Łowmiański, Polityka Jagiellonów, Poznań 1999, s. 475.

72 P. Szpaczyński, Mocarstwowe dążenia..., s. 85.

73 R. Heidenstein, Dzieje Polski..., s. 270-271.

74 „W Krakowie na coronatiey exorbitanciam przez Króla JM dosyć uczyniono”, BN, rkps 6610, k. 48-51. Na brak protestów przeciwko nieinkorporowaniu Estonii zwrócił uwagę W. Leitsch, Sigismund III..., s. 154-155, 157. 
Leśniowolskiego, nazywając króla „niemym diabłem ze Szwecji”75. Przez kolejne lata, zwłaszcza pierwszych pięć, nie mogąc pogodzić się z porażką, usiłował zniechęcić potomka Jagiellonów do panowania w Polsce, ciągle łudząc się, że młody król odjedzie do swego dziedzicznego królestwa niczym niegdyś Henryk Walezy ${ }^{76}$. Ucieczkę tego ostatniego a po niej wybór tak świetnego - w jego ocenie - Batorego przypomniał (poddając pod rozwagę Zygmuntowi) zresztą już na samym początku jego panowania, kiedy stawiał swoje ultimatum na radzie senatu ${ }^{77}$. Król pozostał jednak w Polsce, wykazując ogromną odporność na intrygi i złośliwości Zamoyskiego. Na świat zaczęły przychodzić jego dzieci, w tym następca, który otrzymał imiona Władysław Zygmunt (1595-1648, król od 1632 roku) po założycielu dynastii Władysławie II Jagielle (ok. 1351-1434, król Polski od 1386) i ojcu własnym oraz ojcu i bracie Anny I. Królowa doczekała jeszcze narodzin przyszłego króla i jako matka chrzestna trzymała go do chrztu. Kanclerz Zamoyski na kilka dni przed śmiercią na sejmie w 1605 roku, podkreślając wagę związków dynastycznych dla panowania królów w Polsce, zwrócił się do Zygmunta III słowami: „żeś potomek Jagiełłów, dawnych panów naszych, nie minie korona syna Waszej Królewskiej Mości”78.

Tej chwili nie doczekała już jednak, zmarła nieco dłużej niż rok po narodzinach Władysława (ur. 9 VI 1595), królowa Anna I Jagiellonka (9 IX 1596), która po śmierci Zygmunta II Augusta, swoją osobą niczym nicią skutecznie związała dynastię - Jagiellonów po mieczu z Jagiellonami po kądzieli $^{79}$. Niestety, jak się miało okazać, tylko na jedno stulecie z powodu przedwczesnej śmierci synów i wnuków Zygmunta III. Jego młodszy syn

75 S. Kobierzycki, Historia Wtadystawa królewicza polskiego i szwedzkiego, tłum. z łac. M. Krajewski, wyd. J. Byliński, W. Kaczorowski, Wrocław 2005, s. 33.

76 J. Ekes, Ztota demokracja, Warszawa 1987, s. 142-143, 189; J. Dzięgielewski, Jana Zamoyskiego..., s. 81-88.

77 R. Heidenstein, Dzieje Polski..., s. 270-271; J. Zamoyski o S. Batorym: „Bóg [...] zesłał nam mądrego i walecznego Króla”, J. Bielski, Dalszy ciag..., s. 271.

${ }^{78}$ Mowa Zamoyskiego na sejmie 1605 r., [w:] Pisma polityczne z czasów rokoszu Zebrzydowskiego 1606-1608, t. 2: Proza, wyd. J. Czubek, Kraków 1917, s. 83-96.

79 O tym, że bezkrólewie z powodu ucieczki, po czterech miesiącach pobytu w Polsce, króla Henryka Walezego, trwało w praktyce od śmierci Zygmunta II do wyboru Anny I zob.: S. Płaza, Wielkie Bezkrólewia; Seria „Dzieje narodu i państwa polskiego”, Kraków 1988; zob. też: Bezkrólewia ksiag ośmioro, czyli dzieje Polski od zgonu Zygmunta 
Jan II Kazimierz (1609-1672, król Polski 1648-1668) - ostatni przedstawiciel dynastii Jagiellonów po kądzieli zmarł dokładnie sto lat po śmierci Zygmunta II Augusta, ostatniego Jagiellona po mieczu ${ }^{80}$. Polska pozostawała odtąd królestwem bez dynastii.

Reasumując, należy podkreślić, że od rozstrzygnięcia politycznej rywalizacji pomiędzy Anną I Jagiellonką a Janem Zamoyskim w czasie bezkrólewia po śmierci Batorego zależało bardzo wiele. Determinacja królowej, która walczyła o zapewnienie cią̧łości dynastycznej Jagiellonów, niewątpliwie pomogła jej siostrzeńcowi Zygmuntowi - wnukowi wnuka Jagiełły - w zdobyciu korony. Najpoważniejszym zagrożeniem dla dążeń królowej do osadzenia siostrzeńca na tronie polskim był wszechpotężny kanclerz. Fakt, że niesłusznie przedstawiana w historiografii jako niepozorna i bezbarwna Anna Jagiellonka przejrzała i ograła niedoścignionego mistrza propagandy, jakim był Jan Zamoyski, pozwala zobaczyć królową w zupełnie nowym świetle. To, co nie znalazło zrozumienia u polskich badaczy to fakt, że Zygmunt III czuł się Wazą jedynie jako król szwedzki i Wazą był jedynie w Szwecji, w Polsce zaś, jako król Polski i wielki książę litewski, czuł się Jagiellonem i wraz z synami kontynuował panowanie tej dynastii po kądzieli do 1668 roku $^{81}$. Po śmierci Zygmunta III w 1632 roku, w czasie sejmu elekcyjnego, biskup przemyski Henryk Firlej (1599-1635),

Augusta r. 1572 aż do r. 1576 skreślone przez Świętostawa z Borzejowic Orzelskiego, starostę radziejowskiego, tłum. W. Spasowicz, t. 1-4, Petersburg 1856-1858.

${ }^{80} \mathrm{Na}$ mauzoleum królowej Bony w bazylice św. Mikołaja w Bari, którego budowę zleconą przez Annę I Jagiellonkę - zakończono w 1593 r., widnieją portrety Bony, jej córki Anny I oraz wnuka Zygmunta III, a także herby Bari i Zygmuntowy Orzeł. W połowie XVII w. w mauzoleum Bony dokonano uzupełnień na polecenie Jana II Kazimierza, w związku z czym galeria portretów wzbogaciła się o podobiznę ostatniego Jagiellona po kądzieli i jego żony Ludwiki Marii (1611-1667), która obok Bony była niewątpliwie najwybitniejszą z żon polskich królów, Z. Waźbiński, Mauzoleum Bony Sforzy w Barii, przyczynek do dziejów polityki dynastycznej królowej Anny, ostatniej Jagiellonki, „Folia Historiae Artium" 1979, t. 15, s. 59-87.

${ }^{81}$ Szerzej o tym, że Zygmunt III był „Wazą” w Szwecji, w Polsce zaś wraz z synami kontynuował panowanie dynastii Jagiellonów, por.: P. Szpaczyński, „Wazowie” czy następcy i przedstawiciele dynastii Jagiellonów? Kilka uwag w sprawie problemu ciagtości dynastycznej w Rzeczypospolitej Obojga Narodów po śmierci Zygmunta II Augusta, „In gremium. Studia nad historią, kulturą i polityką" 2007, t. 1, s. 21-37. 
zalecając wybór jego syna królewicza Władysława na tron Rzeczypospolitej, podkreślał, że w jego żyłach płynie „żywa krew Wielkiego Jagiełły”. Prymas Jan Wężyk (1575-1636) z kolei wprost stwierdził, że:

przez tak liczne wieki dwie tylko dynastie, mianowicie Piastów i Jagiellonów, dopuszczono do rządów w naszej ojczyźnie ${ }^{82}$.

Przydomek Waza, który bezceremonialnie od jakiegoś czasu dodaje się zwłaszcza Zygmuntowi III jest sprzeczny z całym materiałem źródłowym, oficjalną tytulaturą władców używaną w korespondencji i widniejącą chociażby na medalach czy monetach. Analogicznych przykładów ciągłości dynastii na wzór Jagiellonów i Wazów w dziejach nie brakuje. Wystarczy chociażby odnieść się do sąsiedzkich dynastii: rosyjskich Romanowów czy austriackich Habsburgów. Dynastia Romanowów, panujących w Rosji od 1613 roku w linii męskiej wygasła w 1730 roku wraz ze śmiercią Piotra II (1715-1730, panował od 1727). Córka Piotra I (1672-1725, panował od 1682), Elżbieta I (1709-1762, panowała od 1741), podobnie jak Anna Jagiellonka zadbała o interes dynastii, doprowadzając, by jej następcą został siostrzeniec Karol Piotr Ulryk Holstein Gottorp (1728-1762). Jako Piotr III objął on tron po śmierci Elżbiety w 1762 roku i w tym samym roku utracił go na rzecz ambitnej żony, urodzonej w Szczecinie księżniczki Zofii Anhalt-Zerbst, znanej w dziejach Rosji jako Katarzyna II (1729-1796). Niemiecka księżniczka nie miała w swoich żyłach ani kropli krwi dynastii, którą reprezentowała, podobnie zresztą, jak jej imienna poprzedniczka, rządząca w latach 1725-1727, żona Piotra I cesarzowa Katarzyna I (Marta Skawrońska, córka chłopa łotewskiego, 1684-1727). Podobnie było z następcą i synem Katarzyny II, Pawłem I (1754-1801), który tylko oficjalnie uznawany był przez współczesnych i uchodzi w dziejach za syna Piotra III. Fakty te nie zostały jednak należycie uwypuklone w historiografii tak, że ostatniego z potomków Pawła I, zdetronizowanego w czasie rewolucji lutowej w Rosji w 1917 roku Mikołaja II (1868-1918, panował od 1894),

82 A. S. Radziwiłł, Pamiętnik o dziejach w Polsce, t. 1: 1632-1636, tłum. i oprac. A. Przyboś, R. Żelewski, Warszawa 1980, s. 261, 265. 
nie sposób określić inaczej niż jako Romanowa ${ }^{83}$. Dynastia Habsburgów z kolei w linii męskiej wygasła w 1740 roku wraz ze śmiercią cesarza Karola VI (1685-1740, cesarz od 1685). Tron cesarski przypadł jego córce Marii Teresie (1717-1780) i jej mężowi, księciu Lotaryngii i Baru Franciszkowi I (1708-1756, cesarz od 1745) oraz ich potomkom ${ }^{84}$. Nie mówi się jednak przez to o końcu dynastii Habsburgów, jedynie czasami dla uściślenia do określenia „dynastia habsburska” dodaje się drugi człon „lotaryńska”; funkcjonuje też określenie „Habsburgowie lotaryńscy”. W historiografii jednak, a przez to i w świadomości historycznej, utrwaliły się określenia „dynastia Habsburgów” i „dynastia Romanowów” w odniesieniu do władców panujących w Austro-Węgrzech i w Rosji niemal do końca I wojny światowej ${ }^{85}$. Wydaje się zatem, że pojęcie ciągłości dynastycznej jest dosyć względne, zależy bowiem od oceny badaczy i przyjętych przez nich kryteriów periodyzacji dziejów własnych państw. W Polsce te kryteria wzięły się z uprzedzeń i porozbiorowej weryfikacji, wyszukiwania bohaterów bez skazy z przeszłości. Wówczas władców podzielono na wybitnych i nieudolnych. Zygmunt III czy Jan II Kazimierz zdaniem owych osiemnastowiecznych weryfikatorów nie pasowali do idealnego obrazu przeszłości, jaki usiłowano kreować ku pokrzepieniu serc, dlatego odcięto ich bezceremonialnie od Jagiellonów, ustalając koniec tej dynastii na 1572 rok. W nielicznych opracowaniach, jak Monarchia Jagiellonów 1399-1586 gdzie górną granicę ustalono na rok 1586, próbuje się nieudolnie skorygować koniec dynastii tak, aby objął i Annę, która przecież w sposób oczywisty była ósmym królem z Jagiellonów ${ }^{86}$. Nieudolnie dlatego, że poprzez fakt śmierci przyda-

${ }^{83}$ Carowie i cesarze rosyjscy z domu Romanow; Cesarze rosyjscy z domu Romanow Holstein-Gottorp, [w:] Genealogia - Tablice, nr 33, 35; W. Serczyk, Romanowowie, [w:] Dynastie Europy, red. A. Mączak, Wrocław 2003, s. 348-363.

${ }^{84}$ Cesarze rzymscy i królowie Modeny z domu Habsburgów i Habsburgów Lotaryńskich, [w:] Genealogia - Tablice, nr 49; S. Grodziski, Habsburgowie, [w:] Dynastie Europy, op. cit., s. 129-130; por.: B. Hamann, Habsburger. Ein biographisches Lexikon, 3. Aufl., Wien 1993.

${ }^{85}$ Historia Europy Środkowo-Wschodniej, t. 1, red. J. Kłoczowski, Lublin 2000, s. $178-180$.

${ }^{86}$ Polska, dzieje cywilizacji i narodu, t. 3: Monarchia Jagiellonów 1399-1586, red. M. Derwich, Warszawa-Wrocław 2003. 
nego Annie za męża Batorego ona „królem” być nie przestała i formalnie była nim nadal aż do śmierci w 1596 roku, co potwierdza dodatkowo to, że przy okazji koronacji w 1576 roku w uwłaczający dla niej sposób szlachta wyłudziła od niej zrzeczenie się spadku po bracie. Wszystko to sprawiło, że woli Anny w czasie elekcji w 1587 roku nie można było zlekceważyć. Królowa-wdowa i król w jednej osobie zgodziła się przemilczeć swoje prawa pod warunkiem wyboru na tron siostrzeńca, który w jej słusznej ocenie miał kontynuować dynastię Jagiellonów w Polsce ${ }^{87}$.

\section{Anna I Jagiellonka versus Jan Zamoyski. Some Remarks about Queen's Pursuance of a Keeping the Jagiellonian Dynasty Continuity}

(SUMMARY)

The article depicts a problem which was not properly analysed by Polish historians. It is a role played by Anna I Jagiellonka during election of her nephew, Zygmunt, to the Polish throne. The issue was neglected mostly because Anna I Jagiellonka was trying to keep continuity of Jagiellonian dynasty through her nephew's election, but historians do not include Zygmunt III neither his sons to this dynasty, finishing it on the 1572 year, without noticing the obvious fact that Anna I was also a king from Jagiellonian dynasty. What is more, after her husband, Stefan Batory's, death, she still was a king. Because of that, her will could not have been disregarded. Queen-widow and in the same time the king in one person agreed to resign from her rights under a condition that her nephew would be elected to the throne. In Anna's justifiable opinion, Zygmunt was able to continue a reign of Jagiellonian dynasty in the Commonwealth of Poland. The most imminent opponent of this idea was the Chancellor and Great Hetman of the Crown, Jan Zamoyski, counter to what hitherto historiography was to suggest. He was an

87 Władysław Konopczyński, wyróżniający się brakiem uprzedzenia w stosunku do Zygmunta III i jego synów, nie miał wątpliwości, że „potomkowie Jagiellonów po kądzieli zapewnili w istocie kontynuację tej dynastii w Rzeczypospolitej Obojga Narodów do 1668 r.”, W. Konopczyński, Dzieje Polski nowożytnej, t. 1: 1506-1648, oprac. J. Dzięgielewski, wyd. 2, Warszawa 1986, s. 152. 
expert of a propaganda and political intrigues, who endeavoured to be elected to the Polish throne and whom Anna I with great diplomatic adroitness imposed her nephew as a proper candidate.

transl. Wiestawa Duży

Przemysław Szpaczyński

e-mail: p.szpaczynski@interia.eu 